\title{
ФТОРИРОВАНИЕ ПОЛИВИНИЛОВОГО СПИРТА ФТОРИСТЫМ КАЛИЕМ
}

Введение фтора в молекулу полимеров позволяет модифицировать их свойства. Непосредственное фторирование поливинилового спирта (ПВС) представляет некоторые трудности, так как замена гидроксильных групп фтором прямым путем требует применения специальных реагентов. ПВС фторировал с помощью четырехфтористой серы (темп. кип. $40^{\circ} \mathrm{C}$ ) В. Безсолицен с сотрудниками, при этом $59,6 \%$ гидроксильных групп было замещено фтором ['].

Фторпроизводные ПВС можно получить гидролизом продукта сополимеризации фтористого винила и винилацетата [2-5].

Задача настоящей работы состояла в разработке нового способа фторирования ПВС в целях получения исходного сырья для синтеза поверхностно-активных веществ и депрессантов.

Для замещения гидроксильных групп фтором в мономерных спиртах известен метод, по которому гидроксильные группы заменяются вначале остатками $n$-толуолсульфокислоты, а потом в полученных $n$-толуолсульфокислых эфирах (тозилатах) тозилоксигруппы заменяются фтором с помощью фтористого калия в подходящем растворителе. В данной работе этот метод получения фторсодержащих соединений использовался для фторирования ПВС.

\section{Методика синтеза}

Использованный в наших опытах ПВС - промышленный образец с молекулярной массой 46000 и с 1,07\%-ным содержанием винилацетатных групп.

$n$-Толуолсульфохлорид марки «ч» дополнительно очищали растворением в смеси петролейного эфира с хлороформом ( $7: 1$ по объему). K насыщенному раствору прибавляли активированный уголь, фильтровали и после почти полной отгонки растворителей выкристаллизовывали мягкий кристаллический $n$-толуолсульфохлорид, который высушивали в воздухе под тягой.

Фтористый калий марки «чда» высушивали при $125^{\circ}$.

11 г (0,25 моля) ПВС тозилировали по методу Рейнольдса и Кениона II В [6]. Для очистки тозилат осаждали из пиридиновой смеси ацетоном или смесью ацетона с гексаном. Растворители удаляли декантированием, продукт повторно промывали теми же растворителями, фильтровали и высушивали на фильтровальной бумаге или сохраняли в ацетоне.

K тозилату ПВС в 250 г дистиллированного диэтиленгликоля (ДЭГ) 
прибавляли сухой фтористый калий и смесь перемешивали при повышенной температуре. В начале реакции перегонялся ацетон (если он присутствовал). После окончания реакции смесь декантировали, полимер осаждали ацетоном и фильтровали, промывали ацетоном и водой до полного удаления фтор-иона в промывных жидкостях. Продукты высушивали при комнатной температуре.

Элементарный анализ подтвердил присутствие фтора и отсутствие серы в продуктах (табл. 1, 2). Содержание ацетильных групп в исходном ПВС $(1,07 \%)$ в расчеты не включается. Количество тозилата ПВС (синтезы $2-5$, табл. 1) вычислено ориентировочно по исходному ПВС и является поэтому повышенным. Примесь солянокислого пиридина в тозилате ПВС (табл. 1) высчитана по содержанию азота (синтезы 2 и 3) или хлора (синтез 1, содержание азота считается повышенным). Предполагается, что в опытах 4 и 5 нефторированные тозилатные и хлоридные группы образуют при нагревании в ДЭГ двойные связи. Побочные реакции экспериментально не исследованы.

\section{Обсуждение результатов}

Синтез n-толуолсульфокислых эфиров - промежуточных продуктов разработанной методики фторирования ПВС - приводится в $\left[{ }^{6-9}\right]$. Наиболее подходящие условия для данной работы предложены Рейнольдсом и Кенионом [6]. Из двух представленных ими методов тозилирования ПВС (II A и II В) мы использовали метод II B, так как имеющийся крупнозернистый ПВС не реагировал однородно без предварительного растворения в воде (и дальнейшего удаления воды).

ПВС тозилируют $n$-толуолсульфохлоридом в пиридине при пониженных температурах $\left(0-10^{\circ}\right) \quad\left(\mathrm{T}_{3}=-\mathrm{SO}_{2}-\mathrm{C}_{6} \mathrm{H}_{4}-\mathrm{CH}_{3}\right)$ :<smiles>CCC(O)C#CC(Cl)C(Cl)Cl</smiles>

Из возможных побочных реакций главной является замена тозилоксигрупп хлором [6]. При проведении тозилирования в оптимальных условиях побочные реакции практически отсутствуют.

Содержание тозилоксигрупп в ПВС определяется элементарным анализом серы в очищенных и высушенных веществах [6-9]. Синтез ПВС с точным числом тозилоксигрупп затруднен из-за отсутствия методики быстрого определения состава полимера в течение реакции.

Нами изучены условия замещения тозилоксигрупп ПВС фтором в присутствии фтористого калия в ДЭГ:

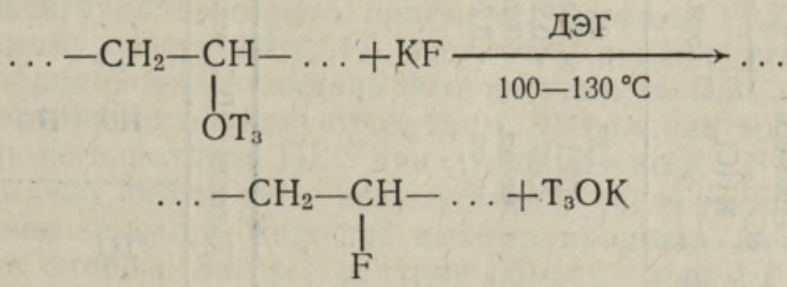

При этом побочными реакциями могут быть отщепление $n$-толуолсульфокислоты с образованием: 1) внутренних эфиров полимера, 2) двойных связей в полимере и 3 ) простой эфирной связи между ПВС и остатками ДЭГ. 


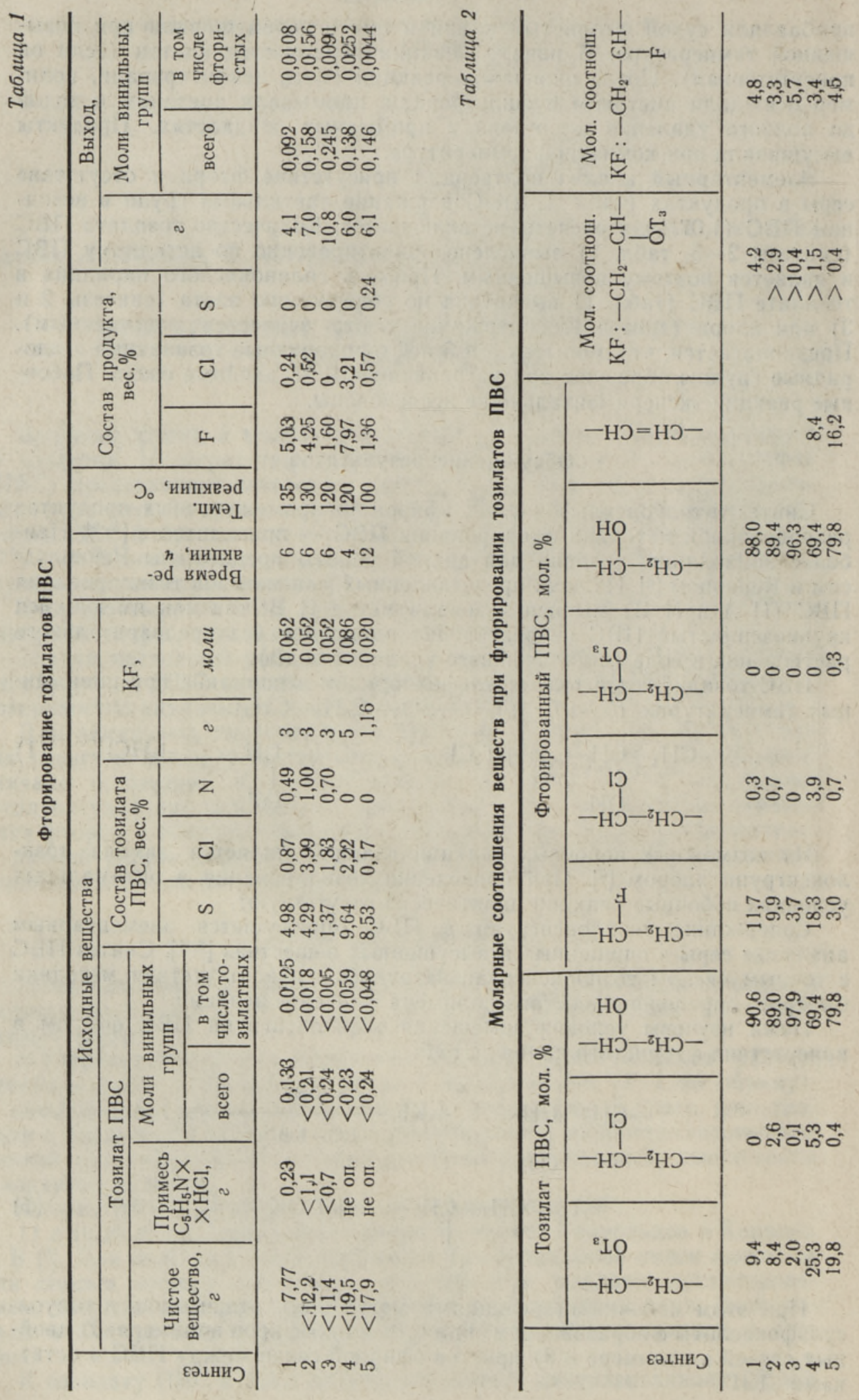


Оказалось, что ПВС с высоким содержанием тозилоксигрупп не вступает в реакцию замещения в ДЭГ. При нагревании в ДЭГ такой полимер стягивается и темнеет. Для фторирования использовали ПВС с низкой или средней степенью замещения гидроксилов (до 25,3\% тозилоксигрупп).

ПВС с низким содержанием n-толуолсульфогрупп является водорастворимым или частично водорастворимым, поэтому в данной работе тозилаты очищали промыванием ацетоном (синтезы 1, 2 и 3, табл. 1 и 2) или смесью ацетона с гексаном (синтезы 4 и 5 , табл. 1 и 2). При этом полимер в некоторой степени задерживает солянокислый пиридин (побочный продукт тозилирования), о чем свидетельствует присутствие азота в аналитических пробах (синтезы 1, 2 и 3, табл. 1). В промытых водой пробах (синтезы 4 и 5, табл. 1) азот отсутствует. Соль пиридина с $n$-толуолсульфокислотой растворяется в ацетоне.

Тозилаты можно хранить под слоем ацетона и в таком виде дозировать в реакционную смесь (синтезы 2-5). Ацетон стабилизирует тозилаты ПВС при комнатной температуре. С увеличением числа тозильных групп растворимость ПВС в ацетоне увеличивается.

Фторирование осуществляли при $100-135^{\circ}$, оптимальной была температура $115-120^{\circ}$. При более высоких температурах увеличивается доля побочных реакций, а при более низких реакция протекает гетерогенно из-за нерастворимости исходного тозилата ПВС в ДЭГ.

Продукты реакции промывали ацетоном (синтез 3) или ацетоном и водой (синтезы $1,2,4,5)$. Полное удаление фтор-иона достигается промыванием водой, но при этом удаляются и более водорастворимые звенья полимера.

Одни и те же показатели содержания тозилоксигрупп в исходном полимере и фтора в конечном продукте (табл. 2) указывают на то, что фтор в конечном продукте химически связан полимерной цепью.

Для фторирования тозилатов ПВС оказался необходимым избыток фтористого калия. Точные соотношения реагентов в данном случае не вычисляемы, так как тозилаты ПВС прибавляли к реакционной смеси в невысушенном виде, чтобы избежать разложения (синтезы 2-5). Предположения об их соотношениях можно делать по количествам исходного ПВС и конечного продукта. При трехкратном избытке фтористого калия (синтез 2) фторирование происходило удовлетворительно. Недостаток фтористого калия способствовал побочным реакциям (синтез 5 ).

Увеличение содержания тозилоксигрупп в ПВС способствует побочным реакциям (синтез 4).

Молярное содержание продуктов определено по элементарному анализу серы, фтора, хлора и азота. Точность определения содержания элементов менее $1 \%$ (табл. 1) относительно мала.

Иногда молярное содержание фтора в продуктах превышает количество тозилоксигрупп исходного полимера (синтезы $1,2,3$ ). Причинами, по-видимому, могут быть: 1) частичная замена хлора фтором, 2) изменение фракционного состава фторированного ПВС при очистке, 3) адсорбция фтористого калия продуктом, 4) влияние побочных реакций (например, дегидратация ПВС при фторировании).

Как показывают результаты исследований, применение настоящего метода позволяет получить хорошие выходы продукта по замещению тозилоксигрупп фтором. За счет реакции обмена хлора на фтор достигается дополнительный выход целевого продукта. 


\title{
Выводы
}

1. Разработан способ неполного фторирования ПВС путем взаимодействия его с $n$-толуолсульфохлоридом и последующим замещением полученных тозилоксигрупп фтором.

2. Показано, что основной реакцией, определяющей состав и выходы фторированного ПВС, является замещение водорода гидроксильных групп ПВС тозильной группой.

\section{Л И ТЕ Р А Т У Р А}

1. Вез солицен В. П., Горбунов Б. Н., Н аз аров А. А., Х а рдин А. П. Высокомолекулярные соед., А 14,950 (1972).

2. Howk, B. W., Pla mbeck, L., Jr., U. S. Pat. 2,499,097; C. A. 44, 4723d (1950).

3. Усманов Х. У., Юльчибаев А. А., Дорджин Г. С., Асамов М. К., Ва. ли ев А., Куз и е в а Х., Ю льчиб а е в а С. Г., Научные труды. Ташкент. гос. унив., № 399, 64 (1970).

4. H a a s, H. C., MacD on a ld, R. L., J. Polym. Sci., Part A-1, 10, 1617 (1972).

5. Tatsuya, B., Tanaka, A., Yamashita, K., Japan 7428,670 ; C. A. 82, 73661 (1975).

6. Reynolds, D. D., Kenyon, W. O., J. Amer. Soc., 72, 1584 (1950).

7. I z a rd, E. F., Morg a n, P. W., Ind. Eng. Chem., 41, 619 (1949).

8. Cohen, S. G., Ha a s, H. C., Slotnick, H., J. Polym. Sci., 11, 193 (1953).

9. L a g a che, M., Ann. Chim., (Paris), [13], 1, (1956).

\author{
Ннститут химии \\ Академии наук Эстонской ССР \\ Поступила в редакцию
}

Salme LAISAAR, S. FAINGOLD

\section{POLOVINUOLALKOHOLI FLUORIMINE KAALIUMFLUORIIDIGA}

Artiklis on esitatud polüvinüülalkoholi fluorimise tulemused. Fluorderivaadid saadi väikese või keskmise $p$-toluoolsulfonüülrühmade (tosüülrühmade) sisaldusega polüvinüülalkoholi kuumutamisel dietüleenglükoolis kaaliumfluoriidi liia korral. On näidatud, et tosüüloksürühmade asendumine fluoriga toimub kergesti ja saagis on hea. Pöhiline reaktsioon, mis määrab fluoritud polüvinüülalkoholi koostise ja saagise, on polüvinüülalkoholi hüdroksüülrühmade vesiniku asendamine tosüülrühmaga.

Salme LAISAAR, S. FAINGOLD

\section{FLUORINATION OF POLYVINYL ALCOHOL WITH POTASSIUM FLUORIDE}

Experimental results of fluorination of polyvinyl alcohol are presented.

Fluorinated polyvinyl alcohol has been prepared by heating the polymer with a low or medium content of $p$-toluene-sulfonoxy (tosyloxy) groups with an excess of potassium fluoride in diethylene glycol. According to the investigation, the replacement of tosyloxy groups by fluorine runs easily and results in good yields. The main reaction determining the composition and yields of fluorinated polyvinyl alcohol is the substitution of hydrogen in hydroxyl groups by tosyloxy group. 